\title{
Determination of Pleurotus abieticola ligninolytic activity on Norway spruce wood
}

\author{
Anna Żółciak \\ Forest Research Institute, Department of Forest Protection, Sękocin Stary, Braci Leśnej 3, 05-090 Raszyn, Poland, \\ phone: +48 227153822, e-mail: A.Zolciak@ibles.waw.pl
}

\begin{abstract}
The effect of Phlebiopsis gigantea treatment in control of Heterobasidion parviporum in Norway spruce is less effective than that in control of Heterobasidion annosum in pine. It is necessary to apply other fungi, for example, Pleurotus abieticola in Norway spruce stands. Thus, it is necessary to assess the activity of major ligninolytic enzymes, that is, laccase, lignin peroxidase (LiP), manganese peroxidase (MnP) and versatile peroxidase (VP) produced by $P$. abieticola, which may be effective in the fast degradation of Norway spruce wood. Three strains of $P$. abieticola (Pa1-3) were grown on pieces of Norway spruce sapwood and heartwood for 50 days in laboratory conditions. Enzymatic activity was determined using spectrophotometry. Pleurotus abieticola produced laccase, $\mathrm{LiP}, \mathrm{MnP}$ and VP. The activity of laccase was low, ranging $0-3.696$ and $0-0.806 \mathrm{mU} / \mu \mathrm{g}$ of protein in sapwood and heartwood, respectively. The highest activity in Pa1 $=3.696 \mathrm{mU} / \mu \mathrm{g}$ of protein in sapwood and in $\mathrm{Pa} 3=0.806 \mathrm{mU} / \mu \mathrm{g}$ of protein in heartwood was observed after 30 and 50 days of incubation, respectively. The activity of LiP was also low, ranging $0-0.188$ and $0-0.271 \mathrm{mU} / \mu \mathrm{g}$ of protein in sapwood and heartwood, respectively. The highest activity in $\mathrm{Pa} 1=0.271 \mathrm{mU} / \mu \mathrm{g}$ of protein in sapwood and in $\mathrm{Pa} 2=0.188 \mathrm{mU} / \mu \mathrm{g}$ of protein in heartwood was observed after 40 and 20 days of incubation, respectively. The activity of MnP ranged $0-17.618$ and $0-12.203 \mathrm{mU} / \mu \mathrm{g}$ of protein in sapwood and heartwood, respectively. This enzymatic activity peaked at the 50th day of culture on sapwood for the Pa3 strain (17.618 mU/ $\mu \mathrm{g}$ of protein) and at the 20th day of culture on heartwood for the Pa1 strain $(12.203 \mathrm{mU} / \mu \mathrm{g}$ of protein). The activity of VP with manganese-oxidising properties was found to be high in all strains of $P$. abieticola, ranging $0-39.19$ and $0-59.153 \mathrm{mU} / \mu \mathrm{g}$ of protein in sapwood and heartwood, respectively, whereas the activity of VP with guaiacol-oxidising properties was very low for all $P$. abieticola strains, ranging $0-0.248$ and $0-0.225 \mathrm{mU} / \mu \mathrm{g}$ of protein in sapwood and heartwood, respectively. The values of released hydroxyphenols in $P$. abieticola strains ranged 24.915-139.766 and 25.19-84.562 $\mu \mathrm{g}$ of protocatechuic acid/ml in sapwood and heartwood, respectively. The values of released methoxyphenols for the evaluated strains of $P$. abieticola ranged 7.225-23.789 and 1.953-20.651 $\mu \mathrm{g}$ of vanillic acid/ml in sapwood and heartwood, respectively. Further studies with a higher number of strains of this species as well as an optimisation of conditions for the measurement of ligninolytic activity are needed.
\end{abstract}

\section{KeY WORDS}

laccase, lignin peroxidase, manganese peroxidase, versatile peroxidase, spruce, white rot fungus, wood 


\section{INTRODUCTION}

The root and butt rot caused by Heterobasidion annosum (Fr.) Bref. sensu lato is considered one of the most important and destructive diseases affecting conifers in the north temperate regions of the world, particularly in Europe where annual loses are estimated at least 790 million euros per year (Woodward et al. 1998; Greig et al. 2001; Korhonen and Holdenrieder 2005; Garbelotto and Gonthier 2013).

In 2018, the disease occurred on 85,125 ha of Polish National Forest [2,782 and 82,343 ha in the first-class age (to 20 years old) and in older tree stands, respectively] (Małecka 2019). Three species of H. annosum s.l. are recorded in Poland: H. annosum (Fr.) Bref. sensu stricto, which affects mostly Scots pine (Pinus sylvestris L.); H. parviporum Niemelä et Korhonen, which affects Norway spruce (Picea abies (L.) H. Karst.; and H. abietinum Niemelä et Korhonen, which affects fir (Abies), rarely spruce and sporadically larch (Larix) (Sierota 2001; Łakomy and Werner 2003).

Heterobasidion annosum s.l. infects with basidiospores, which germinate on fresh stump surfaces after tree cut (Stenlid and Redfern 1998). It then spreads via contacts of diseased and healthy roots of surrounding trees (Rishbeth 1951a, b; 1957; Stenlid and Redfern 1998). One method of control is the application of saprotrophic Phlebiopsis gigantea (Fr.: Fr.) Jülich - a competing fungus that produces the mycelium and fruiting bodies on the surface of the stump surface. The method is successfully applied in many countries. However, the treatment of spruce is not fully satisfactory, amongst others because of too slow wood colonisation process by $P$. gigantea (Korhonen et al. 1994; Holdenrieder et al. 1998; Nicolotti et al. 1999; Berglund and Rönnberg 2004; Nicolotti and Gonthier 2005; Berglund et al. 2005; Rönnberg et al. 2006; Drenkhan et al. 2008; Gunulf et al. 2012; Rönnberg and Cleary 2012). Thus, the more effective competing fungi should be used in the protection of spruce.

Species of Pleurotus may be taken into consideration because of (i) saprotrophic occurrence of Pleurotus ostreatus (Jacq.: Fr.) Kummer on wood of deciduous trees and of Pleurotus abieticola Petersen and Hughes on wood of Norway spruce (Schwarze et al. 2000; Kodrik 2001; Albertó et al. 2002; Żółciak 2002; Szczepkowski and Piętka 2008), (ii) potent ligninolytic enzyme system that enables successful degradation of lignin and various aromatic compounds in wood (Cohen et al. 2002; Stajić et al. 2004; Camassola et al. 2013).

Extremely rare $P$. abieticola has been first described from Far East Russia (Petersen and Hughes 1997) and then reported from China (Albertó et al. 2002; Li et al. 2014; Liu et al. 2015). It can grow on Norway spruce, fir, alder (Alnus) and willow (Salix). In Poland, it has been found in the Białowieża Primeval Forest on Norway spruce (Gierczyk et al. 2015a, b, 2017, 2018; Kujawa et al. 2017).

The aim of this study was to assess the ligninolytic activity of $P$. abieticola strains growing on Norway spruce wood blocks of sapwood and heartwood under laboratory conditions. The results will contribute to the better understanding of metabolic processes of the fungus before its potential application for the control of Heterobasidion.

\section{Material AND Methods}

Three strains of $P$. abieticola (Pa1, Pa2 and Pa3) obtained from basidiospores collected from basidiomata found on the stem of three Norway spruces in the Białowieża Primeval Forest were used in the study. Basidiospores were placed on 2\% malt extract agar (MEA) in Petri dishes. Spores were germinated and mycelium grew at $24^{\circ} \mathrm{C}$ in darkness. After 21 days, the 2-cm diameter discs with mycelium were transferred to sterile 2\% MEA in Petri dishes and incubated at $24^{\circ} \mathrm{C}$ in darkness for another 21 days. Then, the sterile Norway spruce wood pieces of sapwood and heartwood $(80 \mathrm{~mm} \times 40 \mathrm{~mm} \times 4 \mathrm{~mm})$ were placed on P. abieticola mycelium and incubated at $28^{\circ} \mathrm{C}$ in $12 / 12$ hours day/night rhythm for 50 days. The enzymatic activity was analysed in the surface layer of wood covered by mycelium of $P$. abieticola. Samples were collected after 10, 20, 30, 40, and 50 days. Both sapwood and heartwood were ground together and enzyme broth was extracted. Enzyme activities were measured spectrophotometrically (three measurements) in supernatant after centrifuging $\left(6,000 \mathrm{rpm}\right.$. for $5 \mathrm{~min}$ at $\left.4^{\circ} \mathrm{C}\right)$. The amount of enzyme necessary to oxidise $1 \mu \mathrm{mol}$ of substrate per minute was defined as one activity unit. All activities were expressed in units of specific activity $(\mathrm{mU} / \mu \mathrm{g}$ of protein). The activity of laccase was determined with syringaldazine as a substrate (Leonowicz and Grzywno- 
wicz 1981). The activities of lignin peroxidase (LiP) and manganese peroxidase $(\mathrm{MnP})$ were determined using the method of Wariishi et al. (1992) and Tien and Kirk (1988) modified by Matuszewska (2005), respectively.

The activity of versatile peroxidase (VP) in the oxidation of manganese ions and guaiacol was assayed using the method of Sugano et al. (2006). Concentrations of methoxyphenolic and hydroxyphenolic substances were evaluated using diazosulphanilamide in the DASA test (Leonowicz et al. 1968) modified by Malarczyk (1984). Detailed methodology is presented in publications of Żółciak et al. $(2008 ; 2012)$ and Żółciak and Bohacz (2016).

The data on the enzymatic activity were analysed using the Kruskal-Wallis and Mann-Whitney U tests. Statistical analyses were performed using Statistica 10 (StatSoft, Inc.).

\section{Results}

Three strains of $P$. abieticola (Pa1, Pa2, Pa3) whilst growing on both sapwood and heartwood of Norway spruce produced lignin-modifying enzymes, that is, laccase, LiP, MnP and VP (oxidising both manganese ions and guaiacol). During the degradation process, hydroxyphenolic and methoxyphenolic substances were released.

The activity of laccase was low, ranging 0-3.696 and $0-0.806 \mathrm{mU} / \mu \mathrm{g}$ of protein in sapwood and heartwood, respectively. The highest activity in Pa1 $=3.696 \mathrm{mU} / \mu \mathrm{g}$ of protein in sapwood and in $\mathrm{Pa} 3=0.806 \mathrm{mU} / \mu \mathrm{g}$ of protein in heartwood were recorded after 30 and 50 days of incubation, respectively. More often, no activity was observed in heartwood than in sapwood, particularly in case of Pal (Tab. 1). The activity of laccase in three P. abieticola strains and at five periods of incubation (after 10, 20, 30, 40 and 50 days) did not differ significantly. Only the median laccase activity in sapwood and heartwood was significantly different (Fig. 1).

The activity of LiP was also low, ranging $0-0.188$ and $0-0.271 \mathrm{mU} / \mu \mathrm{g}$ of protein in sapwood and heartwood, respectively (Tab. 1). The highest activity in $\mathrm{Pa} 1=0.271 \mathrm{mU} / \mu \mathrm{g}$ of protein in sapwood and in $\mathrm{Pa} 2=0.188 \mathrm{mU} / \mu \mathrm{g}$ of protein in heartwood were recorded after 40 and 20 days of incubation, respectively. The activity of $\mathrm{LiP}$ in $\mathrm{Pa} 1$ and $\mathrm{Pa} 3$ was significantly different (Fig. 2A). The median LiP activity in sapwood and heartwood and at five periods of incubation (after 10, 20, 30, 40 and 50 days) was not significantly different (Fig. 2A).

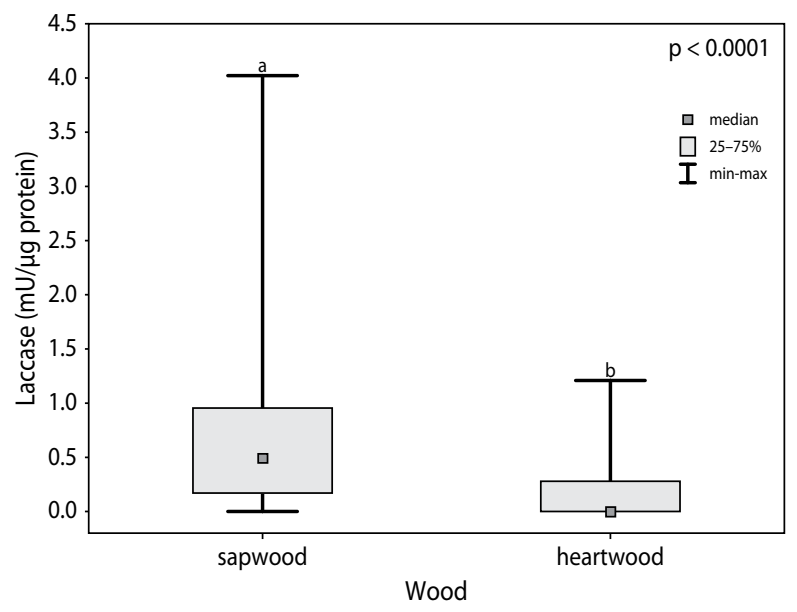

Figure 1. Laccase activity in P. abieticola strains cultured on sapwood versus heartwood (different letters denote statistically significant differences at $\mathrm{p} \leq 0.05$ )

The activity of $\mathrm{MnP}$ ranged from 0 to $17.618 \mathrm{mU} / \mu \mathrm{g}$ of protein in cultures on sapwood and from 0 to $12.203 \mathrm{mU} / \mu \mathrm{g}$ of protein in cultures on heartwood (Tab. 1). The enzymatic activity peaked at the 50th day of culture on sapwood for the Pa3 strain $(17.618 \mathrm{mU} / \mu \mathrm{g}$ of protein) and at the 20th day of culture on heartwood for the Pal strain (12.203 $\mathrm{mU} / \mu \mathrm{g}$ of protein). Strains of P. abieticola $\mathrm{Pa}$ and $\mathrm{Pa} 3$ exhibited $\mathrm{MnP}$ activity in cultures on both sapwood and heartwood. In the case of $\mathrm{Pa} 2$, no manganese activity was noticed. Significant differences were observed between the $P$. abieticola strains $\mathrm{Pa} 1$ and $\mathrm{Pa} 2$ and $\mathrm{Pa} 2$ and $\mathrm{Pa} 3$ in values of $\mathrm{MnP}$ activity (Fig. 2B). On the other hand, no statistically significant differences were observed between the medians of MnP activity in sapwood and heartwood as well as in samples evaluated after days of culture of P. abieticola.

The activity of VP with manganese-oxidising properties was found to be high in all strains of P. abieticola, ranging $0-39.190$ and $0-59.153 \mathrm{mU} / \mu \mathrm{g}$ of protein in sapwood and in heartwood, respectively (Tab. 1). The highest activity of the enzyme was observed for the Pa3 strain (39.19 $\mathrm{mU} / \mu \mathrm{g}$ of protein) at the 30th day of culture on sapwood and for the Pal 
Table 1. Dynamics of measured enzymes activity and levels of secreted hydroxyphenols and methoxyphenols in cultures of P. abieticola strains (Pa1, $\mathrm{Pa} 2$ and $\mathrm{Pa} 3$ ) on Norway spruce wood ( $\mathrm{S}$ - sapwood; $\mathrm{H}$ - heartwood)

\begin{tabular}{|c|c|c|c|c|c|c|c|c|c|c|}
\hline \multirow{3}{*}{ Strain } & \multicolumn{10}{|c|}{ Days } \\
\hline & \multicolumn{2}{|c|}{10} & \multicolumn{2}{|c|}{20} & \multicolumn{2}{|c|}{30} & \multicolumn{2}{|c|}{40} & \multicolumn{2}{|c|}{50} \\
\hline & $\mathrm{S}$ & $\mathrm{H}$ & $\mathrm{S}$ & $\mathrm{H}$ & $\mathrm{S}$ & $\mathrm{H}$ & $\mathrm{S}$ & $\mathrm{H}$ & $\mathrm{S}$ & $\mathrm{H}$ \\
\hline \multicolumn{11}{|c|}{ 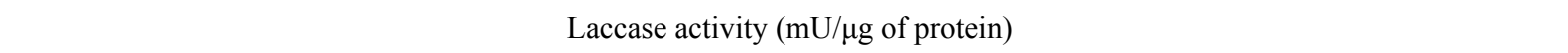 } \\
\hline $\mathrm{Pa} 1$ & 0.373 & 0 & 0.828 & 0 & 3.696 & 0 & 0.176 & 0.340 & 0.179 & 0 \\
\hline $\mathrm{Pa} 2$ & 1.134 & 0.275 & 1.007 & 0 & 0.573 & 0.170 & 0.080 & 0.115 & 0.035 & 0 \\
\hline $\mathrm{Pa} 3$ & 0.768 & 0 & 0.924 & 0 & 0.620 & 0.346 & 0 & 0.781 & 0.202 & 0.806 \\
\hline \multicolumn{11}{|c|}{ 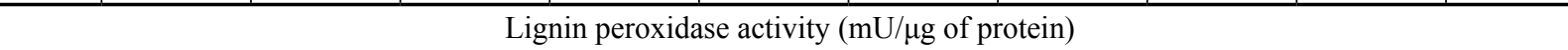 } \\
\hline $\mathrm{Pa} 1$ & 0.051 & 0.067 & 0.074 & 0.105 & 0.168 & 0.050 & 0.071 & 0.271 & 0 & 0.090 \\
\hline $\mathrm{Pa} 2$ & 0.178 & 0.019 & 0.188 & 0.019 & 0.061 & 0.022 & 0.045 & 0.007 & 0.030 & 0 \\
\hline $\mathrm{Pa} 3$ & 0 & 0 & 0 & 0 & 0 & 0.054 & 0.125 & 0 & 0.105 & 0.087 \\
\hline \multicolumn{11}{|c|}{ Manganese peroxidase activity (mU/ $\mu \mathrm{g}$ of protein) } \\
\hline Pal & 5.421 & 4.155 & 9.432 & 12.203 & 8.648 & 9.470 & 10.072 & 10.476 & 6.617 & 7.494 \\
\hline $\mathrm{Pa} 2$ & 0 & 0 & 0 & 0 & 0 & 0 & 0 & 0 & 0 & 0 \\
\hline $\mathrm{Pa} 3$ & 0.177 & 9.509 & 10.003 & 8.779 & 8.794 & 5.662 & 8.100 & 6.711 & 17.618 & 2.032 \\
\hline \multicolumn{11}{|c|}{ Versatile peroxidase activity, oxidising manganese ions (mU/ $\mu \mathrm{g}$ of protein) } \\
\hline Pa1 & 3.863 & 16.249 & 14.143 & 43.057 & 35.680 & 37.949 & 21.376 & 59.153 & 30.020 & 32.898 \\
\hline $\mathrm{Pa} 2$ & 2.020 & 0 & 0 & 0.322 & 0 & 0 & 0 & 0 & 0 & 0 \\
\hline $\mathrm{Pa} 3$ & 2.995 & 27.504 & 29.687 & 44.608 & 39.190 & 31.048 & 31.970 & 32.019 & 38.523 & 9.735 \\
\hline \multicolumn{11}{|c|}{ Versatile peroxidase activity, oxidising guaiacol (mU/ $\mu$ g of protein) } \\
\hline Pa1 & 0.079 & 0.217 & 0.229 & 0.168 & 0.264 & 0.155 & 0.182 & 0.225 & 0.160 & 0.093 \\
\hline $\mathrm{Pa} 2$ & 0.205 & 0.053 & 0.089 & 0.030 & 0.047 & 0 & 0.012 & 0.012 & 0.020 & 0 \\
\hline $\mathrm{Pa} 3$ & 0.248 & 0.178 & 0.270 & 0.137 & 0.213 & 0.065 & 0.082 & 0.157 & 0 & 0.195 \\
\hline \multicolumn{11}{|c|}{ Hydroxyphenols ( $\mu \mathrm{g}$ of protocatechuic acid/ml) } \\
\hline $\mathrm{Pa} 1$ & 43.968 & 75.158 & 77.936 & 84.562 & 139.766 & 71.295 & 61.372 & 78.181 & 58.884 & 70.181 \\
\hline $\mathrm{Pa} 2$ & 69.891 & 34.457 & 66.173 & 28.976 & 44.869 & 25.190 & 27.083 & 70.465 & 24.915 & 70.099 \\
\hline $\mathrm{Pa} 3$ & 71.540 & 80.700 & 89.860 & 83.860 & 83.799 & 63.906 & 45.632 & 74.379 & 77.326 & 56.242 \\
\hline \multicolumn{11}{|c|}{ Methoxyphenols ( $\mu \mathrm{g}$ of vanillic acid/ml) } \\
\hline $\mathrm{Pa} 1$ & 9.090 & 17.749 & 15.493 & 21.250 & 23.789 & 17.258 & 13.076 & 19.170 & 13.197 & 15.520 \\
\hline $\mathrm{Pa} 2$ & 18.321 & 11.743 & 14.477 & 9.191 & 15.514 & 9.191 & 7.871 & 2.242 & 7.225 & 1.953 \\
\hline $\mathrm{Pa} 3$ & 14.901 & 18.779 & 19.015 & 20.651 & 16.369 & 14.786 & 8.767 & 16.301 & 17.426 & 11.581 \\
\hline
\end{tabular}

strain $(59.153 \mathrm{mU} / \mu \mathrm{g}$ of protein) at the 40th day of culture on heartwood. Significant differences were observed between the P. abieticola strains $\mathrm{Pa} 1$ and $\mathrm{Pa} 2$ and $\mathrm{Pa} 2$ and $\mathrm{Pa} 3$ in values of $\mathrm{MnP}$ activity (Fig. 2C). The activity of VP manganese-oxidising properties did not differ significantly amongst cultures of $P$. gigantea strains on sapwood and heartwood or amongst the time periods of strain culture.
The activity of VP with guaiacol-oxidising properties was very low for all $P$. abieticola strains, ranging $0-0.248$ and $0-0.225 \mathrm{mU} / \mu \mathrm{g}$ of protein in sapwood and in heartwood, respectively (Tab. 1). The activity of the enzyme peaked for the Pa3 strain $(0.248 \mathrm{mU} / \mu \mathrm{g}$ of protein) at the 10th day of culture on sapwood and for the Pal strain $(0.225 \mathrm{mU} / \mu \mathrm{g}$ of protein) at the 40th day of culture on heartwood. The activity 
A

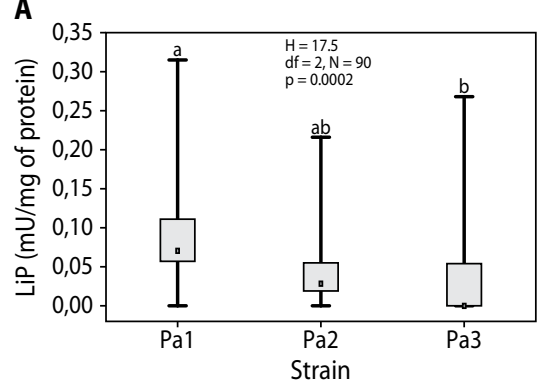

D

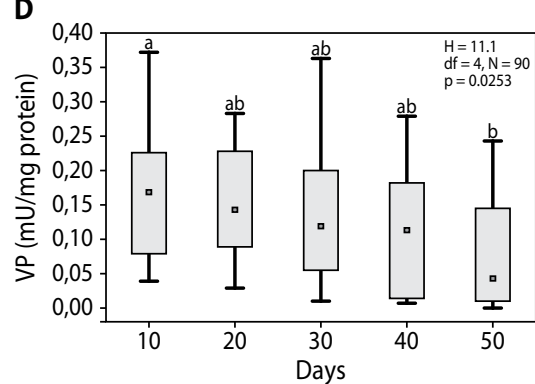

G

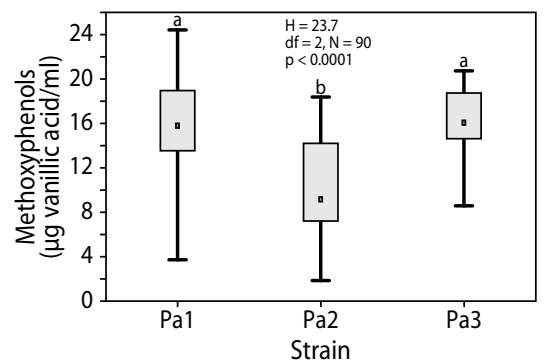

B

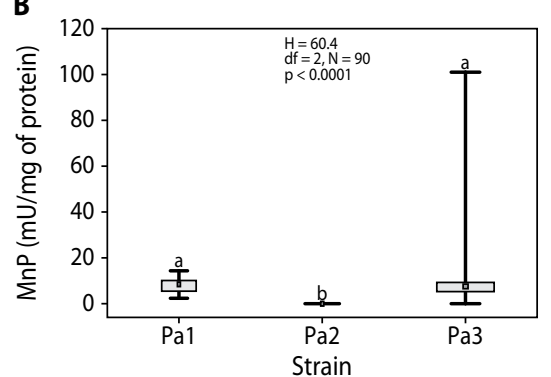

E

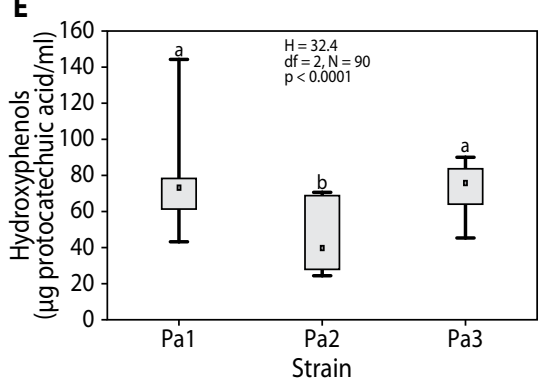

H

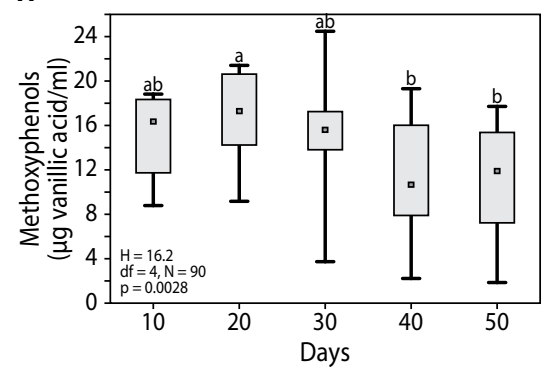

C

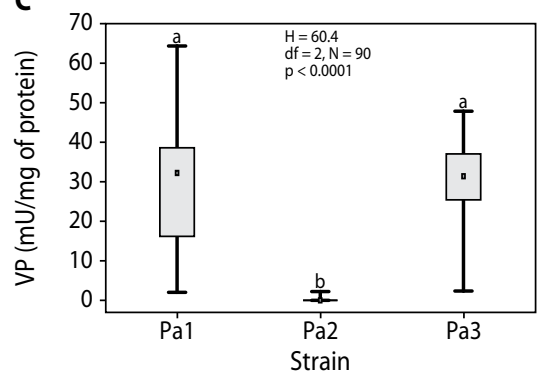

$F$

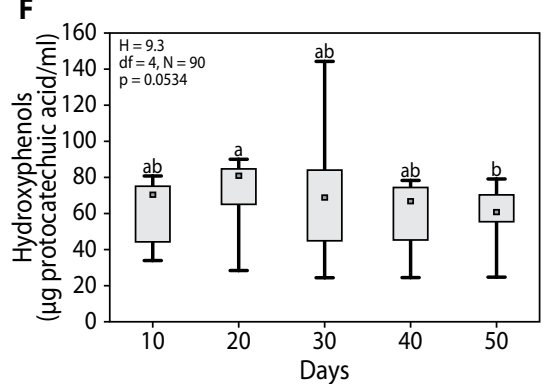

․ median 口25-75\% I min-max

Figure 2. Activity of (A) lignin peroxidase, (B) manganese peroxidase, (C) versatile peroxidase activity oxidising manganese ions in P. abieticola strains, and (D) versatile-oxidising guaiacol comparison amongst culture durations and comparison of median hydroxyphenol production in P. abieticola strains (E) and amongst culture durations (F) and median methoxyphenol production in P. abieticola strains $(\mathrm{G})$ and amongst culture durations $(\mathrm{H})$ (different letters denote statistically significant differences at $\mathrm{p} \leq 0.05$ )

of guaiacol-oxidising VP did not differ significantly amongst the $P$. abieticola strains as well as the $P$. abieticola strains grown on sapwood and heartwood, but statistically significant differences in activity were determined amongst samples evaluated after the 10th and the 50th day of culture (Fig. 2D).

The values of released hydroxyphenols in the $P$. abieticola strains ranged from 24.915 to 139.766 $\mu \mathrm{g}$ of protocatechuic acid $/ \mathrm{ml}$ in cultures on sapwood and from 25.19 to $84.562 \mu \mathrm{g}$ of protocatechuic acid $/ \mathrm{ml}$ in cultures on heartwood (Tab. 1). The highest value of released hydroxyphenols was observed for the Pa1 strain on the 30th day of culture on sapwood (139.766 $\mu \mathrm{g}$ of protocatechuic acid $/ \mathrm{ml}$ ) and on the 20th day of culture on heartwood $(84.562 \mu \mathrm{g}$ of protocatechuic $\mathrm{acid} / \mathrm{ml})$. Significant differences were observed between the $P$. abieticola strains $\mathrm{Pa} 1$ and $\mathrm{Pa} 2$ and $\mathrm{Pa} 2$ and $\mathrm{Pa} 3$ in values of released hydroxyphenols (Fig. 2E) as well as between samples evaluated after the 20th and the 50th days of culture of $P$. abieticola mycelium (Fig. 2F). No significant difference between strains of $P$. abieticola grown on sapwood and heartwood was noticed.

The values of released methoxyphenols for the evaluated strains of $P$. abieticola ranged from 7.225 to $23.789 \mu \mathrm{g}$ of vanillic acid $/ \mathrm{ml}$ in cultures on sapwood and from 1.953 to $20.651 \mu \mathrm{g}$ of vanillic acid $/ \mathrm{ml}$ in cultures on heartwood (Tab. 1). The highest values of 
methoxyphenols were reported for the Pal strain at the 30th day of culture on sapwood (23.789 $\mu$ g of vanillic acid/ $\mathrm{ml}$ ) and for $\mathrm{Pa} 3$ at the 20th day of culture on heartwood (20.651 $\mu \mathrm{g}$ of vanillic acid/ml). Statistically significant differences in the values of released methoxyphenols were observed between the P. abieticola strains Pal and $\mathrm{Pa} 2$, and Pa2 and Pa3 (Fig. 2G) as well as in samples evaluated after the 20th and the 40th, the 20th and 50th days of mycelium culture (Fig. 2H). No significant difference between strains of $P$. abieticola grown on sapwood and heartwood was noticed.

\section{Discussion}

According to Kamitsuji et al. (2004), Pleurotus spp. has been recognised to produce extracellular ligninolytic enzymes such as laccase and MnP. Stajić et al. (2006) showed that laccase and peroxidases production depends on the species and strains of the genus Pleurotus, condition of cultivation and carbon and nitrogen sources and concentrations. In this study, P. abieticola, similar to $P$. ostreatus, secreted laccase and three types of peroxidases, that is, $\mathrm{LiP}, \mathrm{MnP}$ and VP (Leonowicz et al. 1999; Elisashvili et al. 2003; Baldrian et al. 2005; Hoegger et al. 2007).

The results obtained may indicate that $P$. abieticola belongs to groups that produce small amounts of laccase (Bollag and Leonowicz 1984; Baldrian, 2005).

In the present study, the activity of laccase was determined by the oxidation of syringaldazine (Harkin and Obst 1973; Leonowicz and Grzywnowicz 1981), but there are also other methods that may be tested for $P$. abieticola in future studies, for example, laccase production can be stimulated by the presence of a wide variety of inducing substances, particularly aromatic or phenolic compounds (Farnet et al. 1999), anilines (Fåhraeus et al. 1958; Bollag and Leonowicz 1984) or 2,5-xylidine (Fåhraeus and Reinhammar 1967; Rogalski and Leonowicz 1992; Agematu et al. 1993). According to Baldrian and Gabriel (2002), copper and cadmium increase the activity of laccase in P. ostreatus. Stajić et al. (2013) demonstrated a stimulatory effect of the microelements (Fe, $\mathrm{Zn}$ and $\mathrm{Se}$ ) on the activity of laccase in P. ostreatus.

Pleurotus abieticola strains showed a very low ligninase activity. This does not seem to be related to the method of measurement as in the case of laccase. The enzymatic activity of ligninase was measured by the increase in absorbance at $310 \mathrm{~nm}$ under the oxidation of veratryl alcohol (Wong 2009). According to Hammel et al. (1993), veratryl alcohol enhances the action of LiP on many substrates, including lignin (Lundell et al. 1993; Schoemaker et al. 1994), by acting as a mediator (Harvey et al. 1986) or by protecting the enzyme against inactivation (Wariishi and Gold 1989). Guaiacol, acetosyringone, catechol, vanillyl alcohol and syringic acid are other phenolics susceptible to the oxidative potentials of LiP (Harvey and Palmer 1990; Wong 2009). According to Baciocchi et al. (2001), besides the oxidation of non-phenolic substrates, LiP has also shown the capability to oxidise a variety of phenolic compounds.

In this study, the activity of MnP was not so high for the tested P. abieticola strains (except for Pa2 - no activity was noticed). Martinez et al. (1996) reported that the secretion of MnP enzymes by different whiterot fungi is strongly dependent on growth conditions. Manganese peroxidase production was observed in P. eryngii (DC.) Quél., P. ostreatus, P. pulmonarius (Fr.) Quél. and P. sajor-caju (Fr.) Singer in pepton medium, but it was not detected in media with other investigated nitrogen organic sources (corn-step liquor, malt extract and ammonium tartrate).

According to Giardinia et al. (2000), P. ostreatus produces two MnP isoenzymes when grown in solid stationary conditions on poplar sawdust, whereas a lower production of these same enzymes was observed on fir sawdust. Addition of $\mathrm{Mn}^{2+}$ to poplar culture resulted in a threefold increase in the MnP activity; the same addition to fir culture was able to increase 10fold the MnP production. According to Hatakka (1994), $\mathrm{Mn}^{2+}$ ions are a crucial substrate for MnP. This enzyme is a heme glycoprotein that catalyses the oxidation of $\mathrm{Mn}^{2+}$ to $\mathrm{Mn}^{3+}$ in the presence of $\mathrm{H}_{2} \mathrm{O}_{2}$. However, $\mathrm{Mn}^{2+}$ concentration affects the MnP levels; it has been reported (Kerem and Hadar 1993, 1995; Camarero et al. 1996) that the addition of $\mathrm{Mn}^{2+}$ enhances the degradation of lignin during solid-state fermentation of different Pleurotus species, without increasing the MnP levels. On the contrary, the presence of extra $\mathrm{Mn}^{2+}$ strongly increases the production of $\mathrm{MnP}$ during solidstate fermentation on different kinds of wood sawdust (Giardinia et al. 2000). 
In the present study, the activity of VP with manganese-oxidising properties for the focal strains of $P$. abieticola was found to be high in contrast to the activity of VP with guaiacol-oxidising properties. Versatile peroxidase was first reported in $P$. eryngii (Martinez et al. 1996) and then in Bjerkandera adusta [(Willd.) P. Karst.] and P. ostreatus (Sarkar et al. 1997; Heinfling et al. 1998a, b; Mester and Field 1998). Versatile peroxidases combine the properties of LiPs and MnPs, conferring the catalytic versatility inferred by their name (Camarero et al. 1999). According to Ruiz-Dueñas et al. (2001), they can oxidise $\mathrm{Mn}^{2+}$ to $\mathrm{Mn}^{3+}$ similar to MnPs but can also oxidise non-phenolic compounds in the same manner as LiPs.

These preliminary findings on the white-rot fungus P. abieticola are, however, not sufficient to evaluate its capabilities against root rot caused by $H$. parviporum. Further studies with a higher number of strains of this species as well as an optimisation of conditions for the measurement of ligninolytic activity are needed.

\section{ACKNOWLEDGeMENTS}

The present research was supported by the Polish Ministry of Science and Higher Education (MSHE), (Project No 240311). The author wishes to thank Dr. Justyna Bohacz (University of Life Sciences in Lublin, Poland) for enzyme analysis, Dr. Joanna Ukalska (Warsaw University of Life Sciences - SGGW, Poland) for assistance in statistical analysis of data and Dr. Dariusz Karasiński (W. Szafer Institute of Botany Polish Academy of Sciences, Poland) for sending spores of Pleurotus abieticola.

\section{References}

Albertó, E.O., Petersen, R.H., Hughes, K.W., Lechner B. 2002. Miscellaneous notes on Pleurotus. Persoonia, $18,55-69$.

Agematu, H., Kominato, K., Shibamoto, N., Yoshioka, T. 1993. Transformation of 7-(4-hydroxyphenylacetamido)cephalosporanic acid into a new cephalosporin antibiotic, 7-(1-oxaspiro(2.5)octa-6-oxo-4,7diene-2-carboxamido)cephalosporanic acid, by laccase. Bioscience Biotechnology and Biochemistry, 57 (8), 1387-1388. DOI: 10.1271/bbb.57.1387
Baciocchi, E., Gerini, M.F., Lanzalunga, O., Lapi, A., Piparo, M.G.L., Mancinelli, S. 2001. Isotope-effect profiles in the oxidative N-demethylation of N, Ndimethylanilines catalyzed by lignin peroxidase and a chemical model. European Journal of Organic Chemistry, 2305-2310. DOI: org/10.1002/10990690(200106)2001:12<2305::AID-EJOC2305> 3.0.CO;2-E

Baldrian, P., Gabriel, J. 2002. Copper and cadmium increase laccase activity in Pleurotus ostreatus. FEMS Microbiology Letters, 206 (1), 69-74. DOI: org/10.1111/j.1574-6968.2002.tb10988.x

Baldrian, P. 2005. Fungal laccases occurrence and properties. FEMS Microbiology Review, 30, 215-242. DOI: 10.1111/j.1574-4976.2005.0 0010.x

Baldrian, P., Valášková, V., Merhautová, V., Gabriel, J. 2005. Degradation of lignocellulose by Pleurotus ostreatus in the presence of copper, manganese, lead and zinc. Research in Microbiology, 156, 670-676.

Berglung, M., Rönnberg, J. 2004. Effectiveness of treatment of Norway spruce stumps with Phlebiopsis gigantea at different rates of coverage for the control of Heterobasidion. Forest Pathology, 34, 233-243.

Berglung, M., Rönnberg, J., Holmer, L., Stenlid, J. 2005. Comparison of five strains of Phlebiopsis gigantea and two Trichoderma formulations for treatment against natural Heterobasidion spore infections on Norway spruce stumps. Scandinavian Journal of Forest Research, 20 (1), 12-17.

Bollag, J.M., Leonowicz, A. 1984. Comparative studies of extracellular fungal laccases. Applied Environmental Microbiology, 48 (4), 849-854.

Camarero, S., Bockle, B., Martinez, M.J., Martinez, A.T. 1996. Manganese-Mediated Lignin Degradation by Pleurotus pulmonarius. Applied and Environmental Microbiology, 62 (3), 1070-1072.

Camarero, S., Sarkar, S., Ruiz-Dueñas, .FJ., Martinez, M.J., Martinez, A.T. 1999. Description of a versatile peroxidase involved in the natural degradation of lignin that has both manganese peroxidase and lignin peroxidase substrate interaction sites. Journal of Biological Chemistry, 274 (15), 10324-10330.

Camassola, M., da Rosa, L.O., Calloni, R., Gaio, T.A., Dillon, A.J.P. 2013. Secretion of laccase and 
manganese peroxidase by Pleurotus strains cultivate in solid-state using Pinus spp. sawdust. Brazilian Journal of Microbiology, 44 (1), 207-213. DOI: $10.1590 / \mathrm{S} 1517-83822013005000006$

Cohen, R., Persky, L., Hadar, Y. 2002. Biotechnological applications and potential of wood-degrading mushrooms of the genus Pleurotus. Applied Microbiology and Biotechnology, 58 (5), 582-594. DOI: $10.1007 / \mathrm{s} 00253-002-0930-y$

Drenkhan, T., Hanso, S., Hanso, M. 2008. Effect of the stump treatment with Phlebiopsis gigantea against Heterobasidion Root Rot in Estonia. Baltic Forestry, 14 (1), 16-25.

Elisashvili, V., Kachlishvili, E., Chichua, D., Tsiklauri, N. 2003. Lignocellulolytic enzyme activity during growth and fruiting of the edible and medicinal mushroom Pleurotus ostreatus (Jacq.:Fr.) Kumm. (Agaricomycetideae). International Journal of Medicinal Mushrooms, 5 (2), 193-198.

Fåhraeus, G., Tullande,r V., Ljunggren, H. 1958. Production of high laccase yields in cultures of fungi. Physiologia Plantarum, 11, 631-643. DOI: org/10.1111/j.1399-3054.1958.tb08259.x

Fåhraeus, G., Reinhammar, B. 1967. Large scale production and purification of laccase from cultures of the fungus Polyporus versicolor and some properties of laccase A. Acta Chemica Scandinavica, 21 (9), 2367-2378.

Farnet, A.-M., Tagger, S., Le Petit, J. 1999. Effects of copper and aromatic inducers on the laccasses of the white rot fungus Marasmius quercophilus. Compote Rendus de l'Académie des Sciences Series III, Sciences de la Vie/Life Sciences, 322 (6), 499-503. DOI: 10.1016/S0764-4469(99)80100-0

Garbelotto, M., Gonthier, P. 2013. Biology, epidemiology, and control of Heterobasidion species worldwide. Annual Review of Phytopathology, 51, 39-59. DOI: org/10.1146/annurev-phyto-082712-102225

Giardina, P., Palmieri, G., Fontanella, B., Rivieccio, V., Sannia, G. 2000. Manganese peroxidase isoenzymes produced by Pleurotus ostreatus grown on wood sawdust. Archives of Biochemistry and Biophysics, 376, 171-179. DOI: 10.1006/abbi.1999.1691

Gierczyk, B., Kujawa, A., Szczepkowski, A. 2015a. The $20^{\text {th }}$ Jubilee Exhibition of Fungi of Białowieża Forest. Study materials on mycobiota of Białowieża
Primeval Forest (in Polish with English summary). Przeglad Przyrodniczy, 26, 1, 11- 29.

Gierczyk, B., Kujawa, A., Szczepkowski, A. Ślusarczyk, T., Kozak, M., Mleczko, P. 2015b. The $21^{\text {st }}$ Exhibition of Fungi of Białowieża Forest. Materials to the knowledge of mycobiota of the Białowieża Primeval Forest (in Polish with English summary). Przeglad Przyrodniczy, 26, 3, 10- 50.

Gierczyk, B., Ślusarczyk, T., Szczepkowski, A., Kujawa, A. 2017. The 22 $2^{\text {st }}$ Exhibition of Fungi of the Białowieża Forest. Materials to the knowledge of mycobiota of the Białowieża Primeval Forest (in Polish with English summary). Przeglad Przyrodniczy, 28 (1), 59-84.

Gierczyk, B., Ślusarczyk, T., Szczepkowski, A., Kujawa, A. 2018. The $23^{\text {th }}$ Exhibition of Fungi of the Białowieża Forest. Materials to the knowledge of mycobiota of the Białowieża Primeval Forest (in Polish with English summary). Przeglad Przyrodniczy, 29 (2), 9-57.

Greig, B.J.W., Gibbs, J.N., Pratt, J.E. 2001. Experiments on the susceptibility of conifers to Heterobasidion annosum in Great Britain. Forest Pathology, 31, 219-228.

Gunulf, A., Mc Carthy, R., Rönnberg, J. 2012. Control efficacy of stump treatment and influence of stump height on natural spore infection by Heterobasidion spp. of precommercial thinning stumps of Norway spruce and birch. Silva Fennica, 46 (5), 655-665.

Hammel, K.E,. Jensen, K., Mozuch, M., Landucci, L., Tien, M., Pease, E. 1993. Ligninolysis by a purified lignin peroxidase. Journal of Biological Chemistry, 268, 12274-12281.

Hatakka, A. 1994. Lignin-modifying enzymes from selected white-rot fungi: production and role in lignin degradation. FEMS Microbiology Reviews, 13, 125-135. DOI: org/10.1111/j.1574-6976.1994. tb00039.x

Heinfling, A., Martinez, M.J., Martinez, A.T., Bergbauer, M., Szewczyk, U. 1998a. Purification and characterization of peroxidases from the dyedecolorizing fungus Bjerkandera adusta. FEMS Microbiology Letter, 165 (1), 43-50.

Heinfling, A., Martinez, M.J., Martinez, A.T., Bergbauer, M., Szewczyk, U. 1998b. Transformation of industrial dyes by manganese peroxidases from Bjerkandera adusta and Pleurotus eryngii in 
a manganese-independent reaction. Applied and Environmental Microbiology, 64 (8), 2788-2793.

Harkin, J.M., Obst, J.R. 1973. Syringaldazine, an effective reagent for detecting laccase and peroxidase in fungi. Experientia, 29 (4), 381-508. DOI: $10.1007 / \mathrm{bf} 01926734$

Harvey, P.J., Schoemaker, H.E., Palmer, J.M. 1986. Veratryl alcohol as a mediator and the role of radical cations in lignin biodegradation by Phanerochaete chrysosporium. FEBS Letters, 195, 242-246. DOI: org/10.1016/0014-5793(86)80168-5

Harvey, P.J., Palmer, J.M. 1990. Oxidation of phenolic compounds by ligninase. Journal of Biotechnology, 13 (2/3), 169-179. DOI: org/10.1016/01681656(90)90102-H

Hoegger, P.J., Majcherczyk, A., Dwivedi, R.C., Svobodová, K., Kilaru, S., Kües, U. 2007. Enzymes in wood degradation. In: Wood Production, Wood Technology and Biotechnological Impacts (ed.: U. Kües). Universitätsverlag Göttingen, Germany, 389-438.

Holdenrieder, O., Engesser, R., Sieber, T.N. 1998. Biological control of Heterobasidion annosum with Phlebiopsis gigantea on Norway spruce in Switzerland. In: Root and Butt Rots of Forest Trees. 9th International Conference on Root and Butt Rots, September 1-7, 1997 (eds.: C. Delatour, J.J. Guillaumin, B. Lung-Escarmant, B. Marçais). Carcans-Maubuisson, France, 447.

Kamitsuji, H., Honda, Y., Watanabe, T., Kuwahara, M. 2004. Production and induction of manganese peroxidase isozymes in a white-rot fungus Pleurotus ostreatus. Applied Microbiology and Biotechnology, 65, 287-294.

Kerem, Z., Hadar, Y. 1993. Effect of manganese on lignin degradation by Pleurotus ostreatus during solidstate fermentation. Applied and Environmental Microbiology, 59 (12), 4115-4120.

Kerem, Z., Hadar, Y. 1995. Effect of manganese on preferential degradation of lignin by Pleurotus ostreatus during solid-state fermentation. Applied and Environmental Microbiology, 61 (8), 3057-3062.

Kodrik, M. 2001. Results of beech stump inoculation with antagonistic fungi. Journal of Forest Science, 47 (11), 505-512.
Korhonen, K., Holdenrieder, O. 2005. Recent advances in research on the root rot fungus Heterobasidion annosum s.l. A literature review (in German). Forst und Holz, 60, 206-211.

Korhonen, K. et al. 1994. Control of Heterobasidion annosum by stump treatment with "Rotstop", a new commercial formulation of Phlebiopsis gigantea. In: Proceedings of the 8th International Conference on Root and Butt Rots. Wik, Sweden and Haikko, Finland, August 9-16, 1993. IUFRO Working Party S2.06.01. (eds.: M. Johansson, J. Stenlid). Swedish University of Agricultural Sciences, Uppsala, Sweden, 662-667.

Kujawa, A., Gierczyk, B., Kozak, M., Mleczko, P., Ślusarczyk, T. 2017. Diversity of agaricoid, boletoid and hypogeous macrofungi in the Białowieża Forest - project concept and preliminary results. (in Polish with English summary). Fragmenta Floristica et Geobotanica Polonica, 24 (1), 119-131.

Leonowicz, A., Grzywnowicz, K. 1981. Quantitative estimation of laccase forms in some whiterot fungi using syringaldazine as a substrate. Enzyme Microbial Technology, 3, 55-58. DOI: org/10.1016/0141-0229(81)90036-3

Leonowicz, A., Wojtowicz, B., Trojanowski, J. 1968. Model experiment on the humification of rye roots. I. Phenolic products in the humification process. Polish Journal of Soil Science,1, 129-136.

Leonowicz, A., Matuszewka, A., Luterek, J., Ziegenhagen, D., Wojtas-Wasilewska, M. 1999. Biodegradation of lignin by white rot fungi. Fungal Genetics and Biology, 27, 175-185.

Li, Y., Liu, Y., Li, T.H. 2014. Flora fungorum sinicorum. Vol. 45. Pleurotoid-lentinoid fungi (in Chinese). Science Press, Beijing.

Liu, X.-B., Liu, J.-W., Yang, Z.-L. 2015. A new edible mushroom resource, Pleurotus abieticola, in southwestern China. Mycosystema, 34 (4), 581-588. DOI: 10.13346/j.mycosystema.150051

Lundell, T., Wever, R., Floris, R., Harvey, P., Hatakka, A., Brunow, G., Schoemaker, H. 1993. Lignin peroxidase L3 from Phlebia radiata. Presteady-state and steady-state studies with veratryl alcohol and a non-phenolic lignin model compound 1-(3,4-dimethoxyphenyl)-2-(2-methoxyphenoxy) propane-1,3-diol. European Journal of Biochemistry, 211, 391-402. 
Lakomy, P., Werner, A. 2003. Distribution of Heterobasidion annosum intersterility groups in Poland. Forest Pathology, 33 (2), 105-112. DOI: 10.1046/j.1439-0329.2003.00309.x

Malarczyk, E. 1984. Substrate-induction of veratric acid O-demethylase in Nocardia sp. Acta Biochimica Polonica, 31 (4), 383-395.

Małecka, M. 2019. Choroby infekcyjne. In: Krótkoterminowa prognoza występowania ważniejszych szkodników i chorób infekcyjnych drzew leśnych w Polsce w 2019 r. Instytut Badawczy Leśnictwa (in Polish). Analizy i Raporty, 31, 71-82.

Martinez, M.J., Ruiz-Dueñas, F.J., Guillén, F., Martinez, A.T. 1996. Purification and catalytic properties of two manganese peroxidase isoenzymes from Pleurotus eryngii. European Journal of Biochemistry, 237, 424-432. DOI: org/10.1111/j.1432-1033.1996.0424k.x

Matuszewska, A. 2005. The influence of mediators on the degradation of model lignin preparations by Trametes versicolor (in Polish). Doctoral dissertation, UMCS Lublin.

Mester, T., Field, J.A. 1998. Characterization of a novel manganese peroxidase hybrid isozyme produced by Bjerkandera species strain BOS55 in the absence of manganese. Journal of Biological Chemistry, 273, 15412-15417. DOI: org/10.1074/jbc.273.25.15412

Mester T, Field JA. 1998. Characterization of a novel manganese peroxidase-lignin peroxidase hybrid isozyme produced by Bjerkandera species strain BOS55 in the absence of manganese. J Biol Chem 273:15412-15417

Nicolotti, G., Gonthier, P., Varese, G.C. 1999. Effectiveness of some biological and chemical treatment against Heterobasidion annosum on Norway spruce stumps. European Journal of Forest Pathology, 29, 339-346.

Nicolotti, G., Gonthier, P. 2005. Stump treatment against Heterobasidion with Phlebiopsis gigantea and some chemicals in Picea abies stands in the western Alps. Forest Pathology, 35, 365-374.

Petersen, R.H., Hughes, K.W. 1997. A new species of Pleurotus. Mycologia, 89 (1), 173-180.

Rishbeth, J. 1951a. Observations on the biology of Fomes annosus, with particular reference to East Anglian pine plantations. II. Spore production, stump infection, and saprophytic activity in stumps. Annals of Botany, 15, 1-21.
Rishbeth, J. 1951b. Observation on the biology of Fomes annosus, with particular reference to East Anglian pine plantations. III. Natural and experimental infection of pines, and some factors affecting severity of the disease. Annals of Botany, 15, 221-246.

Rishbeth, J. 1957. Some further observation on Fomes annosus Fr. Forestry, 30, 69-89.

Rogalski, J., Leonowicz, A. 1992. Phlebia radiata laccase forms induced by veratric acid and xylidine in relation to lignin peroxidase and manganesedependent peroxidase. Acta Biotechnologica, 12 (3), 213-221. DOI: 10.1002/abio.370120310

Rönnberg, J., Cleary, M.R. 2012. Presence of Heterobasidion annosum infections in Norway spruce stumps six years after treatment with Phlebiopsis gigantea. Forest Pathology, 42 (2), 144-149. DOI: org/10.1111/j.1439-0329.2011.00731.x

Rönnberg, J., Sidorov, E., Petrylaite, E. 2006. Efficacy of different concentrations of Rotstop ${ }^{\circledR}$ and Rotstop ${ }^{\circledR}$ $\mathrm{S}$ and imperfect coverage of Rotstop ${ }^{\circledR} \mathrm{S}$ against Heterobasidion spp. spore infections on Norway spruce stumps. Forest Pathology, 36 (6), 422-433. DOI: $\operatorname{org} / 10.1111 / \mathrm{j} .1439-0329.2006 .00476 . x$

Ruiz-Dueñas, F.J., Camarero, S., Pérez-Boada, M., Martinez, M.J., Martinez, A.T. 2001. A new versatile peroxidase from Pleurotus. Biochemical Society Transactions, 29 (2), 116-122. DOI: 10.1042/BST0290116

Sarkar, S., Martinez, A.T., Martinez, M.J. 1997. Biochemical and molecular characterization of a manganese peroxidase isoenzyme from Pleurotus ostreatus. Biochimica et Biophysica Acta, 1339, 23-30. DOI: 10.1016/S0167-4838(96)00201-4

Schwarze, F.W.M.R., Engels, J., Mattheck, C. 2000. Fungal strategies of wood decay in trees. SpringerVerlag Berlin, Heidelberg, New York.

Schoemaker, H.E., Lundell, T.K., Hatakka, A.I., Piontek, K. 1994. The oxidation of veratryl alcohol, dimeric lignin models and lignin by lignin peroxidase - the redox cycle revisited. FEMS Microbiol Review, 13, 321-332.

Sierota, Z. 2001. Choroby lasu (in Polish). Centrum Informacyjne Lasów Państwowych, Warszawa.

Stajić, M., Persky, L., Cohen, E., Hadar, Y., Brceski, I., Wasser, S.P., Nevo, E. 2004. Screening of the laccase, manganese peroxidase, and versatile 
peroxidase activities of the genus Pleurotus in media with some raw plant materials as carbon sources. Applied Biochemistry and Biotechnology, 117 (3), 155-164.

Stajić, M., Persky, L., Friesem, D., Hadr, Y., Wasser, S.P., Nevo, E., Vukojević, J. 2006. Effect of different carbon and nitrogen sources on laccase and peroxidases production by selected Pleurotus species. Enzyme and Microbial Technology, 38, 65-73.

Stajić, M., Vukojević, J., Knežević, A., Milovanović, I. 2013. Influence of trace elements on ligninolytic enzyme activity of Pleurotus ostratus and P. pulmonarius. Bioresources, 8 (2), 3027-3037. DOI: $10.15376 /$ biores.8.2.3027-3037

Stenlid, J., Redfern, D.B. 1998. Spread within the tree and stand. In: Heterobasidion annosum. Biology, ecology, impact and control (eds.: S. Woodward, J. Stenlid, R. Karjalainen, A. Hüttermann). CAB International, Wallingford, UK, 125-141.

Sugano, Y., Matsushima, Y., Shoda, M. 2006. Complete decolorization of antraquinone dye Reactive blue 5 by the concerted action of two peroxidases from Thanatephorus cucumeris Dec 1. Applied and Environmental Microbiology, 73 (4), 862-871.

Szczepkowski, A., Piętka, J. 2008. Results of inoculation of beech (Fagus sylvatica L.) and oak (Quercus sp.) stumps with Pleurotus ostreatus (Jacq.: Fr.) Kumm. Folia Forestalia Polonica, Series A - Forestry, 49/50, 15-25.

Tien, T., Kirk, K. 1988. Lignin peroxidase of Phanerochaete chrysosporium. Methods in Enzymology, 161, 238-249. DOI: 10.1016/00766879(88)61025-1
Wariishi, H., Gold, M.H. 1989. Lignin peroxidase compound III: formation, inactivation, and conversion to the native enzyme. FEBS Letters, 243, 165-168. DOI: org/10.1016/0014-5793(89)80122-X

Wariishi, H., Valli, K., Gold, H.M. 1992. Manganese (II) oxidation by manganese peroxidase from the Basidiomycete Phanerochaete chrysosporium. Journal of Biological Chemistry, 267, 23685-23695.

Wong, D.W.S. 2009. Structure and action mechanism of ligninolytic enzymes. Applied Biochemistry and Biotechnology, 157, 14-209.

Woodward, S., Stenlid, J., Karjalainen, R., Hüttermann, A. 1998. Heterobasidion annosum. Biology, ecology, impact and control. Preface. Cab International, Wallingford, UK.

Żółciak, A. 2002. Deciduous stump inoculation with Pleurotus ostreatus as biological method of Armillaria root rot control (in Polish with English summary). Prace Instytutu Badawczego Leśnictwa, Seria A, 944, 5-20.

Żółciak, A., Korniłłowicz-Kowalska, T.A., Sierota, Z., Iglik, H. 2008. Enzymatic activity of Phlebiopsis gigantea isolates. Acta Mycologica, 43 (1), 41-48.

Żółciak, A., Sierota, Z., Małecka, M. 2012. Characterization of some Phlebiopsis gigantea isolates with respect to enzymatic activity and decay of Norway spruce wood. Biocontrol Science and Technology, 22 (7), 777-790. DOI: org/10.1080 /09583157.2012.691156

Żółciak, A., Bohacz, J. 2016. Ligninolytic activity of Heterobasidion parviporum isolates in cultivation on Norway spruce wood (in Polish with English summary). Sylwan, 160 (12), 1027-1036. 